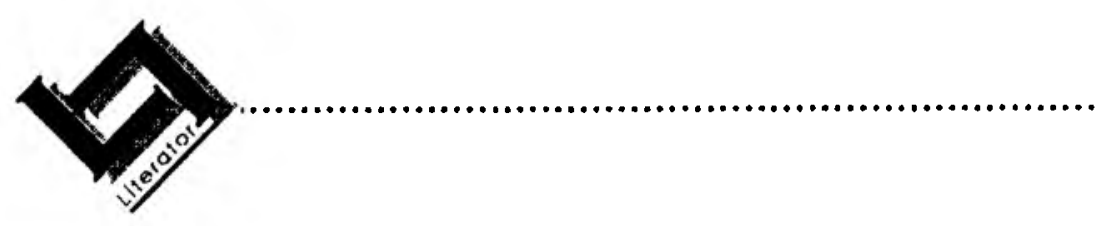

\title{
The moral theme in Zulu literature: a progression
}

\author{
Margaret Marggraff \\ Department of African Languages \\ University of Pretoria \\ PRETORIA \\ E-mail: marggraf@libarts.up.ac.za
}

\begin{abstract}
The moral theme in Zulu literalure: a progression

A moral theme in literature is not only unique to Zulu literature. Despite the relative youth of the modern branch of Zulu literatur, any observer can make the interesting and important discovery that the moral theme is predominantly conveyed by the following three literary types: the folktale, the moral story, the detective story. The folktale, belonging to traditional literature, is a very welldeveloped form, that formed the principal means of teaching both children and adults about good and evil. The birth of modern Zulu literature in 1930 brought with it the emergence of the moral story, a literary type in which good triumphs over evil and in which justice prevails. Further development and changes have led to the appearance of the detective story in which crimes are solved and bad people are punished. This progression has developed due to ever-changing circumstances and $a$ need for relevance.
\end{abstract}

\section{Introduction}

The opposition which constitutes the basis of this article is a universal one and is described as follows by Dresden (1957a:117):

De strijd tussen God en duivel, tussen Goed en Kwaad, is zeker van alle tijden en deze eeuwige tegenstelling kan zich heel goed in alle mogelijke vormen voordoen. 
[The struggle between God and the devil, between good and evil, is surely of all time and this eternal contrast can very well present itself in all possible forms.]

This opposition of good versus evil is the essence of the concept "moral", which is "concerned with goodness or badness of human character or behaviour, or with the distinction between right and wrong" (The Concise Oxford English Dictionary, 1992:769). Best (1991:328) states that "moral" is the implied or stated lecture or lesson contained by a literary work, and indicates the important connection between "moral" and literary work. This connection makes sense as literature is one of the ways in which man expresses and tries to make sense of issues which are very close to his heart. It is self-evident that any literature, and in this case Zulu literature, should have "mechanisms" by means of which the moral theme is expressed. If the moral theme is to remain relevant and is to be of any use to the society in which it is being expressed, then these mechanisms should also be relevant to the time in which they are used. The identification of suitable forms should not be a problem: Dresden (1957a:117) in the quotation provided above talks of "alle mogelijke vormen" ("all possible forms"). In the case of Zulu literature, three major mechanisms conveying the moral theme can be identified to date. Although other literary types might contain elements of the moral theme, the folktale, the moral story, and the detective story are, in chronological order, the predominant conveyors of the moral theme. Each of these literary types was or is relevant to the time in which it appeared or is still appearing, so that the moral theme thus has the impact which its originator wanted / wants it to have. Before this progression is explained, it is necessary to place these three literary types into perspective.

\section{The development of Zulu liferature}

Contrary to wide belief, Zulu has, like many other African languages in South Africa, not only a very well-developed and rich oral literature incorporating among other things, folktales, but also a well-developed written literature. Although classifications of oral Zulu literature differ slightly from one scholar to the next, no scholar denounces the existence of the folktale or inganekwane which is classified as prose by Canonici (1990). Zulu literature, however, differs from other "more established" literatures such as German, French and English in the sense that its written literature developed over a very short period of time and is therefore still comparatively young. Ntuli and Swanepoel (1993:44) state that "The year 1930 is generally regarded as heralding the birth of modern literature in Zulu, with the appearance of Insila kaShaka...." (Modern literature in Zulu" is synonymous with "written literature in Zulu", while the same synonymous relationship applies to "traditional literature" and "oral literature".) Modern Zulu literature is thus only 67 years old, and already has representatives of the five 
major genres, two of the subtypes of the genre novel / novelette being the moral story and the detective story. The relative "youth" of modern Zulu literature makes it possible to observe certain trends very clearly, as these trends have developed over a short period of time, and as the modern literature still finds itself in very close proximity to the traditional literature.

\section{The inganekwane}

The inganekwane (pl. izinganekwane) and other literary types such as izibongo (praise poems), amaculo (songs) and imilolozelo (lullabies) indisputably form part of the traditional oral literature in Zulu despite the fact that they have been reduced to writing. Izinganekwane might still be told and composed to a limited extent in the present day and age. They also live on in written form and are included in the syllabi of educational institutions. Yet it must be accepted that izinganekwane and other forms of traditional oral literature are largely past their prime and are no longer developing to the same extent as they did in the past. Development now takes place in the sphere of written literature. Oral literature in Zulu and probably in most other languages can thus be considered a more or less completed entity.

When Canonici (1990) discusses izinganekwane, then he is referring to a category which he subdivides into izinganekwane or izinsumansumane (folktales), izinganeko (myths) and imizekeliso (legends). He thus uses izinganekwane as an umbrella term as well as to denote a more specific literary type. Msimang (1991) and Makhambeni (1986) similarly subdivide izinganekwane into izinganeko, imizekeliso and izinsumansumane. Ngcongwane et al. (1987) make a different classification. Differences in classification are, however, not the issue in this discussion, nor is the fact that some of the mentioned scholars classify some stories as izinsumansumane when they appear to be more myth-like than anything else. The importance of these classifications and of the discussions of the subtypes can be found in the fact that they all mention the "didactic or teaching element" of the izinganekwane - "teaching" very often deals with the distinction between right and wrong, between what is socially acceptable and what is not. Msimang (1991:49) identifies a specific type of insumansumane in this regard, namely the insumo which, according to him, teaches lessons. This didactic function identified by Msimang can be brought into line with a comment made in 1975 by Scheub as quoted in Canonici (1990:30): "The storyteller never preaches, but she always deals with this essentially moral problem of the good in man and his potential for evil".

The izinganekwane are past their prime. The Zulu people traditionally had a rural way of life. The herding of cattle, the tilling of fields, the fetching of water, the veneration of ancestors, and the occasional fight or battle constituted the 
everyday life of a society in which each member of the family had clearly-defined duties to perform. One of the roles of the grandmother was to tell stories at night. The advent of urbanization and industrialization broke families apart, and more and more Zulus started living in towns and cities, where other norms existed and where the way of life was vastly different from a rural existence. Even though the grandmother might still have been at home in the rural areas with her grandchildren, the absence of the family-head who could be working in the mines would realign the duties in the home, and the opportunity for story-telling might very well have been lost. If a mother and her children went to live with her husband in the urban areas, the grandmother might not have gone along, due to lack of space or other factors.

Under such changed circumstances folktales lost their immediate relevance (the term "folktale" is used here and in the ensuing discussion as an umbrella term encompassing izinsumansumane, izinganeko and imizekeliso). Yet there had been a time when they were relevant, when they were the best way of conveying the moral theme. In the times of long ago there were no formal schools for Zulu children, and they received their education at home (Canonici, 1990:28). "There were no policemen to enforce the law: society provided to the punishment of evil deeds and the encouragement of good trends especially through the tales" (Canonici, 1990:28). The often unrealistic and supematural happenings in the tales did not detract from their effectiveness - realism was not a requirement, and the folktales were well-received.

\section{- The polarity of good versus evil}

All izinganekwane contain the basic polarity of "good versus evil". Canonici (1990:22) refers to the five basic needs of folktales - as indicated by Bascom in 1965 - and states that two of the five basic needs served by the folktales in any given society are validation of culture, of beliefs and rituals, and education. The vindication of one's culture reflects a belief that culture is something worthwhile, something which should not be lost. To educate someone is to give him or her "intellectual, moral, and social instruction" (The Concise Oxford Dictionary, 1992:373). The basic polarity between good and evil can also be detected in some of the seven sequences and twenty four functions which Canonici (1990:37) distinguishes as being applicable to Zulu folktales (relevant sequences and functions will differ from culture to culture). Canonici (1990:37) identifies the binary opposition violation and obedience which follows on the interdiction and command functions: "A positively obeyed COMMAND is followed by a positive CONSEQUENCE; VIOLATION instead is followed by punishment, or a negative CONSEQUENCE" (Canonici, 1990:39). Canonici $(1990: 31,38)$ furthermore states that a folktale starts off in harmony, but that a situation of imbalance or disequilibrium then sets in. The plot eventually moves to the climax, order is restored, and "Even in the most desperate situations, a folktale shows that 
balance can be recuperated; it is a lesson that one should never allow (oneself) 1 to be crushed by pessimism" (Canonici, 1990:31).

Although the moral theme is present in all folktales, it is more obvious in some than in others. The insumo "Impisi Nethambo" ("The hyena and the bone") in Msimang (1991:75) is an example of a folktale in which the moral theme is conveyed explicitly. In this story, a hyena finds an old bone of a buck after a hard day's futile hunting, and picks it up with its mouth. When it crosses a river, it sees the reflection of the moon in the water, and confuses the moon with a lump of meat. It drops the bone in the river and tries to grab the reflection of the moon, but all to no avail. When the other animals hear this story, they laugh and say that only the hyena could be so stupid to throw away a buck which it had in its possession.

\section{- Fables or animal stories}

Canonici (1990:18) states that in fables or animal stories (Ezezilwane), animals are chosen to represent specific human qualities, and that the hyena represents gluttony and foolishness. These stories offer "the opportunity for a criticism of society and for social satire; for moral education" (Canonici, 1990:18). Msimang (1991:49) calls this type of folktale izinganekozilwane ("animal myths"). In these folktales, the origin of the behaviour of animals is explained or a particular defect is clarified, but at the same time they also teach lessons about human behaviour, about customs which should be preserved, about the results of bad habits such as murder, hatred, jealousy (Msimang, 1991:49). In the inganekozilwane "Uheshane Nezinkukhu" ("The hawk and the chickens"), a hawk and a hen initially get on very well and even get married. Their relationship turns sour when the hen loses the hawk's axe which she has promised to look after very well. The hawk gets very angry and decides to punish the hen despite her pleading. He tells the hen that he will eat her chicks from that day. It is also from that day that hens scratch the ground: they are still searching for the hawk's lost axe. Although the message in this story is clear, namely that one must keep one's promises and look after things which have been entrusted to one's care, the reader / listener cannot help wondering whether the hawk is not perhaps a little too hard on the hen. The hen did after all try to find the axe and pleaded with the hawk who was, however, relentless. Although the reader realizes that the hen was wrong in breaking her promise, he questions the rightness of the hawk's actions. A judgement pronouncing the hawk as good and the hen as bad would be an over-simplified one, and would not present a true reflection of what really happened. The hawk has the right to be angry but he does not have the right to be so harsh. The hen in turn has no right to lose the axe but she does have the right to be pardoned after

1 This word was changed by the author of this article and replaces 'himself' in the original quotation. 
right to be pardoned after pleading. The classification of good and evil in folktales is therefore not always simple.

\section{- Trickster stories}

Trickster stories constitute another subcategory of izinganekwane. In these stories in which mainly Chakijana but also Phoshozwayo and Nogwaja occupy the role of the trickster it is also not always immediately obvious what the good or the evil entails. The difficulty to make sense of good and evil can be attributed mainly to the fact that the animal trickster normally gets away with hideous crimes. In this context mention can be made of the folktale "UChakijana Bogcololo" ("The slender mongoose") which can be found in Izaqheghe (Rich creamy milk [Makhambeni, 1986]) but which manifests in other forms as well. In this story, Chakijana offers to look after the babies of a lioness as the latter has to go out and look for some food. Chakijana kills one baby after the other, cooking and feeding them to their own mother, but tricking the lioness into believing that all her cubs are still alive. In the end, Chakijana tells her the truth, but escapes her anger. Chakijana is the villain in this case, and it seems as though evil triumphs in this story. The lioness had to leave her cubs to find food for them, and there is no reason to believe that she was in any way neglecting her motherly duties: "Nempela lahamba ibhubesi kodwa inhliziyo yalo isemuva emawundlwini alo" ("Indeed, lion left but her heart stayed behind with her cubs" [Makhambeni, 1986:15]). When she returns from her hunting one day she sees her cubs sitting with a half-human half-animal, and she gets very angry. Although this creature introduces himself as Chakijana Bogcololo (the slender mongoose) which should ring a bell in her mind, she is only too willing to allow Chakijana to be a babysitter. It must, however, be said that Chakijana won her trust by faking concern for the cubs and by stating that there were dogs hanging around the den. $\mathrm{He}$ has thus deceived the lioness and she has allowed herself to be deceived. Despite thus showing strength of character, the lioness has made the mistake of not seeing through Chakijana. Chakijana's deed of cooking someone's children and letting the mother eat them without being aware of it is horrific, but at the same time the lioness should have realized what was going on.

Canonici (1990:29) points out that trickster stories "impart a kind of preventive education: don't do as the trickster does, and be aware of tricksters in society". Such an assessment of trickster tales makes clear their moral function. This moral value is also clear in the book entitled Ucakijana Bogcololo (The slender mongoose [Mbata \& Mdhladhla, 1927]) which is a collection of trickster tales. In an introduction to this collection, D. Mck. Malcolm, the then "Chief Inspector of Native Education", states that he commends the collection for the use in schools where Zulu is taught. It is then probably with the school situation in mind that the authors divide their tales into lessons which are often concluded by messages with regard to behaviour: 
- Ni-bo ba xwaya omaqinase (Mbata \& Mdhladhla, 1927:22) [Be wary of precocious children]

- A kuko 'qili 'lazikot 'emhlane (Mbata \& Mdhladhla, 1927:38)

[There is no cunning person who ever licked his own back]

- Lalelani abazali benu (Mbata \& Mdhladhla, 1927:54) [Listen to your parents] ${ }^{2}$

\section{- Human beings in Zulu izinganekwane}

Zulu izinganekwane do not only have animals or half-animals like Chakijana as their characters, but also human beings. Canonici (1990:28) states that "Most human tales arise from a wrong which must be put right, or from a break in human relationships or in social harmony which must then be restored". If, for example, a group of girls decide to kill the king's daughter because they do not like her, and then bury her alive, then there is a wrong which must be put right, a disturbance in social harmony which has to be corrected. This happens in "UBuhlaluse Benkosi" ("The king's Buhlaluse" [Canonici, 1986:187-192]), in which Buhlaluse is the victim of an evil deed. She has done nothing wrong but finds herself in the undesirable position of not being liked by her fellows. They are overcome by an evil spirit and there is nothing which redeems them in the eyes of the beholder after they have attempted to kill Buhlaluse: they lie about Buhlaluse's whereabouts and say that she got lost. Although Buhlaluse is found before she dies, and eventually recovers, the harsh judgement which the girls receive for an unforgivable deed seems fair: "Zabulawa zonke zagqitshwa khona lapho zazigqibe khona uBuhlaluse beNkosi" ("They were all killed and were buried in the place where they had killed the king's Buhlaluse" [Canonici, 1986:1921).

"Before the upheaval caused by white colonization, the main means of ... moral ... education for a Zulu child consisted of listening to the stories told by the grandmother" (Canonici, 1995:21). However, in the face of new challenges, new problems and the definite beginning of a written literature, Zulu culture had to transfer the role of moral theme conveyor from the folktale to another literary type.

\section{The moral story}

Groenewald (1976:13) in an article entitled "Die moraalstorie" states that the love-story Moelelwa, published in 1940, is not only the first successful written narrative in Northem Sotho literature, but is also a bridge between the oral and

2 The original orthography has been retained in the above quotations as well as with regard to the names of the authors of UChakijana Bogcololo [The slender mongoose].) 
the written narrative as it functions as a moral story in the place of the traditional narrative with its didacticism. Similarly, Lindenberg et al. (1965:15) state the following about the first publications in Afrikaans: "Hulle is didakties en moraliserend van aard; 'n sterk prekerige tendens slaan oral in die geskrifte deur". Moralizing and teaching was also present in the early years of the English novel. If the moral story phenomenon chronologically coincides with early written literature in languages such as Northern Sotho, Afrikaans and English, then it is reasonable to assume that a similar situation will exist in Zulu literature, and that the moral story in Zulu will take over the role of moral theme conveyor from the folktale as is the case in Northem Sotho literature.

Investigations reveal that the above assumption is true. Marggraff (1994:7) identifies five moral stories in Zulu for the time period 1930 to 1955. In these stories the moral theme is inseparably connected with both the "Jim-goes-to Jo'burg" motif as well as the "prodigal son" motif. Both of these motifs serve to make the moral story a relevant conveyor of the moral theme. These motifs appear in a time in South Africa in which urbanization and industrialization are the order of the day:

... migration to the city and the main characters' contact with Makgoweng (Workplace and Western life-style), their physical and cultural dislocation and their moral destruction which eventually leads to a catharsis and often a return home (Ntuli \& Swanepoel, 1993:56).

Typical moral story heroes like Jabulani in Nyembezi's Mntanami! Mntanami! (My child! My child! - 1950) or Delsie Moya in Dhlomo's Indlela Yababi (The evil way - 1946) grow up in rural areas. After rebelling, they run away from home to the city where they are corrupted. They eventually recognize their mistakes and repent like the prodigal son in the Bible. These protagonists are representative of many young South Africans of that time-period - youths who grew up in rural areas and who thought that a city like Johannesburg would be a welcome escape from poverty and "ignorance". Groenewald (1976:21-22) states that the main character of the moral story is someone with both good and bad qualities, and the conflict between good and evil can be found in the struggle between virtue and vice in the same character. This person is basically good, has a shortcoming, is punished for trespassing, and is eventually pardoned (Groenewald, 1993:3). The hero of Mntanami! Mntanami! (My child! My child!) complies with the requirements of Groenewald's moral story hero. Jabulani is characterized as a polite, well-brought-up boy who initially abides by his parents' rules and regulations. It is only after having been punished by his parents for something which he did not do, that Jabulani starts rebelling and that his weaknesses such as defiance start coming to the surface. 
In the folktale, the listener is taught directly or indirectly about qualities which he should or should not have, about behaviour which he should or should not engage in, about how or how not to deal with life's problems. A similar situation exists in the moral story: ".. die tema word in 'n moraal saamgevat wat op die leser se moreel-etiese waardes ' $n$ beroep doen, en so bepaal dat die onreg nie ongestraf mag gaan nie" (Groenewald, 1976:25). [ ... the theme is summarized in a moral which appeals to the reader's moral-ethical values and in this way determines that the injustice may not go unpunished.]

\section{- The moral story: guilt and penance}

The moral story is all about guilt and penance - the main character has to do penance after every error, and only then does he or she become honourable again in the eyes of the reader (Groenewald, 1976:25, 27). The climax of this type of story is found in the most important moment of penance (Groenewald, 1976:27). Jabulani, the protagonist of Nyembezi's moral story Mntanami! Mntanami! (My child! My child!) must thus show some kind of remorse after he has been arrested for stealing some money, this latter offence being the culmination of a number of "smaller offences" such as smoking and drinking. While he is in jail waiting for the hearing he thinks about his father and his mother, and is worried about what they will say when they hear about his imprisonment. When he later sees his father during the hearing, he is filled with shame and looks away. It is morally right that the injustice which exists after people have been robbed of their money, be corrected, and this is what happens. Jabulani and his accomplices in crime are punished, and the good has triumphed over the evil

Jabulani eventually decides to run away to Johannesburg. When he gets off the train in Johannesburg he feels very lonely and thinks to himself that had there been a train going back to Natal at that time and had he had money, he would not have hesitated to get on to the train. These thoughts reflect a form of repentance after he has run away from home without telling anyone. Jabulani's most important moment of penance succeeds his murder of an innocent little boy. Jabulani did not really want to kill him, but was forced to do so. From this point onwards his life becomes unbearable. His conscience leaves him no peace and he wonders what his parents would say if they had to hear that he is a murderer. The spiritual fight taking place within Jabulani is a fight between good and evil and the good eventually wins, this signalling the climax: Jabulani decides to hand himself over to the police. He is prepared to let the world know what he has done, and to face his punishment, the consequences of his terrible deed. Jabulani externalizes his decision to hand himself over to the police with words directed to a parson: 
'Baba angiboni ukuthi ikhona enye indlela. Kungcono khona baba ukuba ngiyozinikela ngithole isijeziso leso esingifanele. Akukho okunye Baba' (Nyembezi, 1950:200).

'Father, I do not see another option. It is better if I hand myself over and receive the punishment which I deserve. There is nothing else, Father.']

Jabulani's punishment for the murder amounts to five years in a reformatory. He has redeemed himself in the eyes of the reader, and the narrative can end as justice has been done (cf. Groenewald, 1976:25).

\section{- The issue of apartheid}

The intention of the writer of the moral story is to moralize. In some moral stories in Zulu the writer takes morality and ethics a step further by touching on another issue which was very relevant in the time in which these stories were created, namely the issue of apartheid. In most cases strict censorship would have made any form of political criticism very difficult and even impossible, and comments would have had to be very subtle. In Mntanami! Mntanami! (My child! My child!), black people require passes to move from one province to the next, and young white men do not have respect for old black men, but instead use the colour of their skin as justification for rude behaviour:

Usho kubani ukuthi umfana? Awuboni ukuthi ngimhlophe? (Nyembezi, 1950:28).

['Whom are you calling boy? Don't you see that I am white?']

The moral story as a conveyor of the moral theme must be relevant to the time in which it is set. Readers must be able to identify with situations which they come across in the story and then decide whether what is happening is good or bad. In a time in which apartheid dominated the life of every South African citizen, it was inevitable that it too should become a moral and ethical issue. As was, however, the case with the folktale, the moral story also reached a point in its development when its significance started waning, and it became time for the moral theme to look for a new vehicle by means of which it could be transported. This new vehicle was the detective story.

\section{The detective story}

The detective story in Zulu literature is a relatively new development and is not yet as established in Zulu as it is in other African languages such as Northern Sotho. The detective story in Zulu has therefore not yet come of age which explains why this literary type still has shortcomings. The only writer to date of Zulu detective stories is Meshack Masondo. As moral stories manifest mainly in the earlier stages of the development of a written literature, it is self-evident that 
Zulu literature should also reach a stage in its development when it has outgrown the moral story; when new literary types emerge. In an environment in which mass-migration to the city is no longer the most pressing issue, a new moral theme conveyor which is socially relevant, is necessary. The detective story deals with crimes like murders, robberies, corruption and blackmail which are all part and parcel of everyday and contemporary South African life. It is precisely the "criminal" nature of the detective story which allows for the clear depiction of what is opposite to crime and disorder, and it is thus understandable that the detective story should succeed the moral story as moral theme conveyor.

A link between the moral story and the detective story might seem strange at first as these two literary types are different in many respects. Groenewald (1976: 13), however, links these two literary types and classifies them as code stories with regard to Northern Sotho literature. This classification also applies to Zulu literature. In the code story, the writer appeals to the reader as a moral being, to someone who can distinguish between good and evil and who will side against the evil (Groenewald, 1976:14). The writer therefore expects the reader to condemn murder, corruption and blackmail, and to congratulate the detective when he has completed his task successfully. For the purposes of Iphisi Nezinyoka (The expert hunter and the snakes), Masondo's first detective story, the writer expects the reader to condemn Nsakansaka Nkosi's murder of Bheki Hlophe, and to denounce Magwegwe Buthelezi's deception and his abuse of his position of power as manager of the Nation Bank. Similarly the reader must pat Themba Zondo, the detective hero of this detective story on the back after he has solved the case and after he has brought the criminals to justice. Code stories reflect a strong form of objectivity on the part of the writer - his handling of matters reflects his personal uninvolvement which explains the absolute indifference to death in the detective story (Groenewald, 1977:19). When Zondo discovers the corpse of Bheki Hlophe, he factually takes note of the situation:

Yabe igqoke ibhulukwe eliluhlaza kanye neyembe elimhlophe. Yayiphezu kwedamu legazi. Wathi qalaqala uZondo, wase ekhothama eyibheka le ndoda eyabe idindilizile. Wakhangwa inxeba elikhulu entanyeni yale ndoda (Masondo, 1990:38).

[He was wearing a green pair of trousers and a white shirt. He was lying in a pool of blood. Zondo looked hither and thither and then bent down to look at the stretched-out man. His aftention was caught by a big wound situated on the neck of this man.]

Zondo does not stop to ponder the unfaimess or tragedy of the murder of this old man - rather, his mind races in an attempt to try and fit together the pieces of the puzzle which led to Hlophe's death. This indifference towards death brings to mind an identical situation in the folktale in which the most gruesome happenings 
are portrayed in such a way that the beholder is not shocked by them at all. Mention can be made here of the inganekwane "UNogwaja Neselesele" ("The hare and the toad"), which ends as follows:

Yagungquza intenesha, isha, ishaya isizibekelo izama ukusivula iphume. akwaze kwasiza lutho ngoba kwakwelekwe itshe elisindayo phezu kwaso. Yasha yaze yafa intenesha ... (Canonici, 1986:47).

[The hare rattled, got angry, beat the lid trying to open it and to get out, but it was no use because there was a heavy stone on top of it. The hare burned to death ... (Canonici, 1986:48).]

In all three literary types being discussed, the reader is not expected to be involved in a deeply emotional manner. $\mathrm{He}$ is not expected to experience "pathos" and the consequent "catharsis". The moral is the primary issue in these types, and the reader is expected to make a moral judgement, to correctly interpret the moral theme by siding with the good against the evil.

Dresden (1957:93) claims that at a first glance it might appear as though the detective story is a very realistic literary type, but that this is not the case. Dresden (1957b:93-102) motivates this claim by stating that both the detective as well as the suspect are larger than life, and that the absolute rationalising and patterning of reality makes the detective story unrealistic. The detective becomes a super-hero, somebody who always unravels the mystery, who always survives and always comes out on top. This makes him a type, and in the words of Dresden (1957b:101) a marionette which does what it is instructed to do. These characteristics of the detective story lead Dresden (1957b) to the conclusion that the detective story is a "sprokie":

In deze sprookjeswerkelijkheid bestrijden twee machten elkaar, en gelijk het in sprookjes betaamt weet men van te voren welke macht het winnen zal. De prins-detective zal er voor zorgen dat het goede uiteindelijk en ondanks alle moeilijkheden overwint.

[In this fairy-tale reality, two powers are fighting each other, and as is proper in fairy-tales, one knows from the beginning which force is going to win. The prince-detective will see to it that the good will eventually conquer despite any difficulties.]

What might at a first glance seem like an analogy between totally different parties actually makes sense when observed from Dresden's point of view. When a reader encounters a moral story he also expects the good to triumph over the evil in the end and the analogy between folktale and detective story can therefore be extended to include the moral story. 
In Iphisi Nezinyoka (The expert hunter and the snakes), the role of creating order out of chaos is allocated to Themba Zondo. Zondo has to show that justice will prevail and that all is not lost. True to type, Zondo is a very accomplished worker whose experience allows him to make the following statement: isiqiniseko siphendula isimangaliso. IsiZulu sithi ungamethembi umuntu ... (“... certainty changes into a strange happening. Zulu says not to trust anyone ..." [Masondo, 1990:8]). His "fame" stretches far and thus makes him the most suitable candidate for investigating the robbery at the Nation Bank in Johannesburg: Ngathatheka kakhulu indlela owabe uphenya ngayo amacala okwebiwa kwezimoto eThekwini ("I was really impressed by the way in which you investigated the car theft cases in Durban" [Masondo, 1990:6]). He is an umakadebona (Masondo, 1990:13), a person who is very wise and who knows when he might pick up a clue. On the other hand he also knows when he should rather withhold information from fellow characters. Zondo is a very brave man and does not give up his investigation until he has revealed the truth. Not even an attempt on his life keeps him from persevering with the unravelling of the puzzle. His ability to make sense of happenings which nobody else could make sense of elevates him to the position of Dresden's "prince-detective".

In the end, the criminals in Iphisi Nezinyoka (The expert hunter and the snakes) are captured and after one of the police-officers in this story hits and kicks one of the criminals, Zondo says the following: Myeke manje Mhlobo. Uzosithola isigwebo esimfanele ("Leave him now, Mhlobo. He will receive a suitable judgement" [Masondo, 1990:125]). Zondo here gives literal expression to the moral soundness which he stands for. Zondo knows that Nsakansaka Nkosi, the man whom Mhlobo Mvubu was kicking, will receive his punishment, and it is therefore not necessary for Mvubu to mete out punishment. Although the reader is not told what the punishment will be, and despite an unconventional ending to the story involving some men with guns, the reader trusts Zondo when he says that the punishment will be suitable and that he is satisfied that justice has prevailed. Dresden (1957a:118-119) describes the demands of the reader in this context as follows:

De lezer eist, ook al is hij zich dat niet voortdurend bewust, een immanente rechtvaardigheid, dat betekent een recht waarvan de voltrekking in deze wereld plaats moet vinden en zichtbaar worden.

[The reader, although not continuously being aware of it, demands immanent justice. This justice must be visible and must be executed in this world].

In Masondo's third detective story entitled Ingalo Yomthetho (The long arm of the low), it is not the detective, Makhosonke Ndima, who makes the final breakthrough, but rather his girlfriend Popi Hadebe. Despite this unorthodox 
approach which is compounded by a strange ending very similar to the one found in Iphisi Nezinyoka (The expert hunter and the snakes), the reader is satisfied that justice has prevailed. As is the case in Iphisi Nezinyoka (The expert hunter and the snakes), the reader is not told what sentences the two biggest criminals, Makhosazana Nxumalo and Jona, are to receive. After the exposure of these two criminals, the judge merely says that they must be kept in a suitable place until their day of sentencing. This statement satisfies the reader and he can rejoice together with all the people who were present at the trial: Emva kwesikhashana yachitheka inkantolo benokuthokoza okukhulu bonke abantu ("After a while, the court dispersed and all the people were very happy and grateful" [Masondo, 1994:167]).

\section{Conclusion}

As modern Zulu literature is still in its infancy, scholars are still expecting a lot of development to take place: "We are optimistic about the future of this literature" (Ntuli in Gerard et al., 1993:154). Whether or not Zulu literature will live up to such expectations, remains to be seen. It is also only the future which will tell whether a literary type like the detective story will attain the same level of maturity which has been attained by, for example, the folktale. In addition, time will reveal which new "mechanism" will succeed the detective story as moral theme conveyor.

\section{Bibliography}

Best, OF. 1991. Handbuch literarischer Fachbegriffe. Frankfurt : Fischer Taschenbuch Verlag.

Canonici, N.N. 1986. Izinganekwane - An Anthology of Zulu Folktales. Durban : University of Natal.

Canonici, N.N. 1990. The Zulu Folktale. Durban : University of Natal.

Canonici, C.C. 1995. Folktale performance as an educational experience. Southern African Journal for Folktale Studies, (6):13-23.

Dresden, S. 1957a. Recht en moraal. In: Dresden, S. \& Vestdijk, S. Marionettenspel met de dood. Den Haag : Bert Bakker. p. 117-125.

Dresden, S. 1957b. Sprookjeswerkelijkheid. In: Dresden, S. \& Vestdijk, S. Marionettenspel met de dood. Den Haag : Bert Bakker. p. 93-102.

Gérard, A S. et al. 1993. Comparative Literature and African Literatures. Pretoria : Via Afrika.

Groenewald, P.S. 1976. Die moraalstorie. Studies in Bantoetale, (3) $1: 13-38$.

Groenewald, P.S. 1977. Die speurverhaal. Studies in Bantoetale, (4)1:19-45.

Groenewald, P.S. 1993. The Development of the Didactic Novel in Northern Sotho. Pretoria University of Pretoria

Lindenberg, E. et al. 1965. Inleiding tot die Afrikaanse letterkunde. Pretoria : Academica.

Makhambeni, N.M. 1986. Izaqheghe. Pretoria : De Jager-HAUM.

Marggraff, M.M 1994 The Moral Story in Zulu (1930-1955). Pretoria : University of Pretoria. (M.A. dissertation.)

Masondo, M.M. 1990. Iphisi Nezinyoka. Johannesburg : Educum Publishers. 
Masondo, M. 1994. Ingalo Yomthetho. Pietermaritzburg : Shuter \& Shooter.

Mbata, A.H.S. \& Mdhladhla, G.C.S. 1927. Ucakijana Bogcololo. London : Simpkin, Marshall Hamilton, Kent.

Msimang, C.T. 1991. Inkosi Yinkosi Ngabantu. Pretoria : Out of Africa Publishers.

Ngcongwane, S.D., Maphumulo, A.M. \& Thwala, J.J. 1987. Umlalazi. Arcadia : Bard Publishers.

Ntuli, D B. \& Swanepoel, C.F. 1993. Southem African Literature in African Languages. Pretoria : Acacia.

Nyembezi, Sibusiso. 1950. Mntanami! Mntanami! APB : Johannesburg.

Nyembezi, Sibusiso. 1946. Indlela Yababi. Pietermaritzburg : Shuter \& Shooter.

The Concise Oxford Dictionary. 1992. Oxford : Oxford University Press. 
